\title{
THE SYSTEM OF ORAL JUSTICE AND ITS SCIENTIFIC AIMS TO EXPLAIN ANTISOCIAL BEHAVIOR
}

\author{
José Paulino Dzib Aguilar*, Verónica Godoy Cervera**, \\ Carlos Alberto Macedonio Hernández ${ }^{* * *}$, Lucely Martina Carballo Solís ${ }^{* * * *}$ \\ In the present article we analyzed the importance of the application of \\ the scientific method and the interdisciplinary work that gives reliability \\ and validity to expert valuation, that contribute to the judges in the work of \\ impart justice. For do this, they approach the antisocial phenomena that \\ have an impact on the justice system, school violence and the syndrome of \\ parental alienation, and the current problems in them, as well as the \\ contributions of legal psychology in its study and understanding. Finally, \\ some future lines of work are discussed.
}

INTRODUCTION.......................................................................... 764

I. BULlying ClASSIFIED BY THE LAW AS SCHOOL ViOLENCE ....................765

II. Methodology for Diagnosing Alienation Parental ...................770

III. THERAPEUTIC JUSTICE IN YUCATAN ............................................... 774

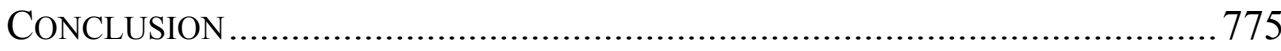

\section{INTRODUCTION}

One of the objectives of the system of oral justice established in Mexico since 18 June 2008, is the use of the scientific methods in the administration of justice. To implement such process some issues need to be considered from different approaches, which will be discussed by providing possible explanations for the antisocial behavior using the scientific approach. The first focal point is the practice of valid and reliable scientific methodologies. The second focal point is the development of competencies and the third one is the introduction of an interdisciplinary approach.

The scientific methodologies which need to test their validity and

\footnotetext{
* Doctor in Social Problems, Faculty of Psychology, Universidad Autónoma de Yucatán. Research fields: Forensic Psychological Evaluation and Forensic Psychopathology.

${ }^{* *}$ Master in Forensic, Faculty of Psychology, Universidad Autónoma de Yucatán. Research fields: Risk of Violence and Credibility of the Testimony.

*** Juris Doctor, coordinator of academic group (Multidisciplinary and Tridimensional Vision of the Law), College of Law, Universidad Autónoma de Yucatán. Research fields: Law and Social Reality.

${ }^{* * * *}$ Master in Law, academic dean and member of the academic group (Multidisciplinary and Tridimensional Vision of the Law), College of Law, Universidad Autónoma de Yucatán. México. Research fields: Law and Social Reality.
} 
reliability are in the area of justice for children and adolescents, in relation to school violence, commonly known as bullying. The term is confusing for the judiciary because school violence is defined from different points of view, which do not completely apply in the legal field. Therefore, the problem will have to be contextualized.

\section{BULlying Classified By the LAW AS SCHOOL ViolenCE}

Regarding school violence in Mexico, $40 \%$ of the children and young people said they had suffered bullying ${ }^{1}$. Bullying started to be studied in the $70 \mathrm{~s}^{2}$, with some theories developed by Dan Olweus, who called Bullying to some types of physical or psychological abuse from one student to another ${ }^{3}$. Such phenomenon was studied from three perspectives: a. Health; b. social and school, and c. law, as antisocial behavior ${ }^{4}$.

The United Nations Organization has declared bullying as a serious problem because it damages the physical, psychological and social development of children and adolescents, and also violates their human rights $^{5}$. According to the World Health Organization ${ }^{6}$ Violence is defined as:

The intentional actual use of strength or physical power, or as a threat, against oneself, another person, a group or a community; that cause or has high probabilities of causing injuries, death, psychological damages, development disorders or deprivations.

Intentionality is the main characteristic that distinguishes bullying from other negative behaviors. According to Dzib-Aguilar, Godoy-Cervera, Castillo \& Ordóñez (2010), ${ }^{7}$ bullying can be classified as a form of community violence.

\footnotetext{
${ }^{1}$ L. Delgadillo Guzmán, and F. Argüello Zepeda, El bullying unamanifestación de deterioroen la interacción social entre pares, 9(3) RA XIMHAI 65-80 (2013). Zapata, E. y Ruiz, R., Respuestas institucionales ante la violencia escolar, 11(4) RA XIMHAI 475-491 (2015).

${ }^{2}$ M. Chapell, S. L. Hasselman, T. Kitchin, S. Lomon, K. Maclver, and P. Sarullo, Bullying in Elementary School, High School and College, 41(164) AdOLESCENCE, 633-648 (2006).

${ }^{3}$ D. Olweus, Low School Achievement and Aggressive Behavior in Adolescent Boys. En D. \&. Magnusson, HumAn DeVElopment, AN INTERACTIONAL PERSPECTIVE 353-365 (EstadosUnidos: Academic Press 1983).

${ }^{4}$ E. Zapata, and R. Ruiz, Respuestas institucionales ante la violencia escolar, 11(4) RA XIMHAI 475491 (2015).

${ }^{5}$ U. Zurita, Los desafios del derecho a la educaciónenméxico a propósito de la participación social y la violencia escolar, 16 ReVISTA MeXICANA DE InVESTIGACIÓN EdUCATIVA 131-158 (2011).

${ }^{6}$ Organización Mundial de la Salud. Informemundialsobre la violencia y la salud (Washington, D. C. 2003).

${ }^{7}$ P. Dzib-Aguilar, V. Godoy-Cervera, R. Castillo Ayuso, and L. Ordoñez Puc. Lagunas de intervención profesional del bullying en México. En Fuensanta López Rosales (Comp.). Prospectiva de la Psicología de la Salud en México. Consorcio de Universidades Mexicanas 163-183 (2010).
} 
Bullying refers to the interaction between peers that is characterized by the persistence of one of the participants in intimidating and bothering another person, in different ways ${ }^{8}$. School violence is expressed in different negative behaviors that can happen inside, as well as outside the school, and may be infrequent, and not always by the same participants. Therefore, bullying should not be confused with other disruptive behaviors or indiscipline. $^{9}$

Criteria to discuss about bullying:

(a) The negative behaviour is intentional.

(b) The abuse is repeated.

(c) Imbalance between the power of the abuser and the victim's.

(d) There is a control-submission relationship between the abuser and the victim.

(e) Aggression can be focused on one individual o more.

(f) Aggressions can be carried out by one individual or more.

(g) The antisocial behavior occurs in the school environment.

There are different opinions among the non-expert users of the concept of bullying regarding the number or people who participate in the violent behavior in the school environment. If the purpose is to understand the phenomenon of school violence, it is important to consider three actors who can interact and exchange roles depending on the time and levels of power and submission. The three actors in school violence are:

(1) The abuser: Bully.

Who acts violently against one or more of his partners who considers weak, due to their physical, social or cognitive conditions. In most of the cases, the bullies are boys. The girls practice other types of violence, mainly psychological or virtual.

There are three main types of aggressors: a) The active aggressor who abuses directly; b) the social aggressor that abuses through manipulation of other partners; and c) the passive aggressor, the one who is usually the follower of a leader ${ }^{10}$.

(2) The victim: Bullied.

The ones who receive the aggressions, frequently they have a feeble

\footnotetext{
${ }^{8}$ G. Pérez, Dinámica del bullying y psicopatologíaenadolescentes, 3 REVISTA DE LA SOCIEDAD DE PSiQuiatría Biológica del Uruguay 15-25 (2004). F. Cerezo, Variables de personalidadasociadasen la dinámica bullying (agresores versus víctimas) enniños y niñas de 10 a 15 años, 17 ANALES DE Psicología 37-43 (2001).

${ }^{9}$ R. Ruiz, M. Riuró, and M. Tesoro, Estudio del bullying en el ciclo superior de primaria, 18(1) EDUCACIÓN XXI 345-368 (2015).

${ }^{10}$ D. Santoyo, and S. Frías, Acoso escolar en México: actores involucrados y sus características, 44(4) REVISTA LATINOAMERICANA DE ESTUdios EdUCATIVOS 13- 41 (2014).
} 
physical appearance or are of a shy character and introverted; also they have difficulty for socializing and making friends. The victims can be men as well as women; men usually suffer physical aggressions whereas the women suffer psychological aggressions ${ }^{11}$.

The consequences of being victims of bullying is shown through nervousness, stomach discomforts, headaches, night fears, anxiety, fear of going to school and isolation. These consequences can continue for years, even through adulthood ${ }^{12}$.

(3) The observers

The observers also are involved in the systematic school bullying, although in an indirect way, therefore their participation is usually unnoticed.

As Trianes Torres $^{13}$ states there are three types of observers: a) The active observers, who directly support the aggressor; b) the passive observers who indirectly support the aggressor; and, c) the prosocial observer who provides support to the victim.

The phenomenon of school violence can be practiced from different roles and these can change into different forms; as aggressor, victim or observer. In the scientific field it is known that the main characteristic of violence (in its different modalities) is that it originates from different factors, therefore it makes it difficult to determine which is the most important element or factor. Therefore, school violence has been studied from different disciplines. There are two periods in the study of bullying. The first period includes the statistical studies presented in the works of Olweus, Heinemann and Roland. The second period, from the beginning of 2000 , is characterized by paying attention to qualitative elements of bullying ${ }^{14}$. Reducing the study of bullying to the elements previously mentioned is to ignore factors such as social, cultural, emotional and cognitive; as well as the social, economic or political context, which can be related directly or indirectly. Considering the complexity of bullying without reducing its study to personality variables that interact among peers in the school environment.

Bullying has a cycle that usually starts up with a specific conduct and then it becomes a systematic behavior towards the victim, which produces, in the victim, a persistent fear of being attacked, and establishes power of

\footnotetext{
${ }^{11}$ D. Olweus, Bullying Is Not A FACT OF Life (Noruega: SAMHSA 2003).

${ }^{12}$ C. Baeza-Herrera, F. Vidrio-Patrón, B. Martínez-Leo, and A. Godoy-Esquivel, Acososevero entre iguales ("bullying"). El enemigo entre amigos, 31(4) ACTAPEDIÁTRICA DE MÉXICO 149-152 (2010).

${ }_{13}$ M. TRianes TorRes, La violencia en CONTEXTOS ESCOLAREs (Málaga: Aljibe 2000).

${ }^{14}$ L. Castillo-Pulido, El acoso escolar. De las causas, origen y manifestaciones a la preguntapor el sentido que le otorganlosactores Magis, 4(8) REVISTA INTERNACIONAL DE INVESTIGACIÓNEN EDUCACIÓN 415-428 (2011).
} 
control on the abuser ${ }^{15}$.

Aggression has been normally seen as a type of motivation not only based on the desire for control and status but as well as a way to obtain specific benefits and even satisfaction by hurting other people ${ }^{16}$. Accepting aggression as socially valid and valued medium ${ }^{17}$.

Piñuel \& Oñate ${ }^{18}$ suggest that there are five stages in the development of bullying and school intimidation.

- First, incidents that start the process. It could be a previous relation between aggressor and the victim, neutral or positive, however, a trivial event triggers the roles of control and submission.

- $\quad$ Second, stigmatization at school, society and the family: Finding a scape goat. The process begins by name calling, intimidation and mockery. The idea that the victims deserve the violence and bullying that they receive.

- Third, consistency and acceptance of psychological defenselessness.

- Fourth, development of psychological and psychosomatic symptomatology. The victims show signs and symptoms of bullying. Symptomatology is variable therefore diagnosis is unclear.

- Fifth, rejection or self-isolation of the victim from school and social environment and prolongation of the damage.

It is worth mentioning that the school bullying exists in a new virtual modality, which happens beyond the school premises, among people who spend time together at the school environment. This type is called cyberbullying, which refers to bullying through electronic means ${ }^{19}$.

The advance of research, expressed in the different classifications of roles and stages appeals for joining efforts between science and law to set standards for better school relationships.

The family plays an important role in school bullying, because it is a variable that is built outside this environment and influences the spaces in which the peers interact, which is the school. The family is the first group in which the individual develops the sense of belonging, where the norms and guidelines for relationships that rule in the society are learned, hence its direct and indirect influence on the violence and the school bullying. Parents

\footnotetext{
${ }^{15}$ F. Cerezo, Bullying: análisis de la situaciónen las aulasespañolas, 9(3) INTERNATIONAL JOURNAL OF PSyCHOLOGY AND PSyChOLOGICAL THERAPY 383-394 (2009).

${ }^{16}$ C. Santoyo, L. Colmenares, N. Figueroa, A. Cruz, and E. López, Organización del comportamientocoercitivo de niños de primaria: un enfoque de sintesis, 25(1) REVISTA MEXICANA DE Psicología $71-87$ (2008).

${ }^{17}$ E. Chaux, Agresión reactiva, agresión instrumental y el ciclo de la violencia, 15 REVISTA DE ESTUDIOS SOCIALES 47-58 (2003).

${ }^{18}$ I. Piñuel, and A. Oñate, Acoso Y Violencia Escolar (Madrid: TEA 2006).

${ }^{19}$ M. Campbell, Cyberbullying: An Old Problem in a New Guise?, 15 Australian Journal of GuidanCE AND COUNSELLING 60-76 (2005).
} 
have a relevant role in the physical, cognitive, emotional and social development of the children, they are expected to be sensitive to their needs and to promote the establishment of safe relationships and bonds ${ }^{20}$.

Conflicts and violent situations between parents are elements associated with violent behavior among children and adolescents. ${ }^{21}$ The adolescents who choose violence as paramount form of relation with others are usually teenagers that come from permissive homes with ambiguous limits ${ }^{22}$.

Moving from the family to a wider context; Mexico heads the list of countries with greater incidence of school bullying in the last years. In a report published by the Organization for the Cooperation and Economic Development (OCED), Mexico is in the first place in reported cases of bullying. $40 \%$ of children in sixth grade of elementary school reported to have been robed inside the school premises.

The National Commission of the Human rights (CNDH) reported that $30 \%$ of the students of elementary school suffered bullying, this figure increased to $40 \%$ in 2013. In other words, in Mexico nearly 18 million 781,875 students of primary and secondary schools are victims of systematic bullying at school. The numbers presented include both public and private schools, and they clearly show that the problem is increasing. ${ }^{23}$

Because of that, diverse laws have been created in many nations including Mexico, because violence damages the dignity, integrity and education of the individual ${ }^{24}$. The first federal program for the development of a safer school environment in Mexico was created in 2007. ${ }^{25}$ In 2012 the 61 st term of office of the Chamber of Deputies in Mexico promoted the Federal Law to Prevent, Treat and Eradicate School Intimidation. At present there are around twenty state laws, and initiatives of law, as measures against school violence ${ }^{26}$.

\footnotetext{
${ }^{20}$ J. Vargas, E. Ibáñez, and S. Javier, Evaluación del vínculo de adolescents problemáticos, 8(3) Revista EleCtrónica de Psicologíalztacala 28-57.

${ }^{21}$ E. Romera, R. Del Rey, and R. Ortega, Factores Asociados a la Implicaciónen Bullying: Un Estudioen Nicaragua, 20(2) PSYCHOSOCIAL INTERVENTION 161-170 (2011). S. Verlinden, Hersen, and J. Thomas, Risk Factors in School Shootings, 20(1) Clinical Psychology ReVIEW 3-56 (2000).

${ }^{22}$ S. Eljach, ViolenCIA ESCOLAR ENAMÉRICA LATINA Y EL CARIBE. SUPERFICIE Y FONDO (Panamá: UNICEF 2011).

${ }^{23}$ L. Delgadillo Guzmán, and F. Argüello Zepeda, El bullying unamanifestación de deterioroen la interacción social entre pares, 9(3) RA XIMHAI 65-80 (2013). E. Zapata, and R. Ruiz, Respuestas institucionales ante la violencia escolar, 11(4) RA XIMHAI 475-491 (2015).

${ }^{24}$ E. Zapata, and R. Ruiz, Respuestas institucionales ante la violencia escolar, 11(4) RA XIMHAI 475-491 (2015).

${ }^{25}$ U. Zurita, Los desafios del derecho a la educaciónenméxico a propósito de la participación social y la violencia escolar, 16 Revista MeXiCANA DE InVESTIGACIÓn EdUCATIVA 131-158 (2011).

${ }^{26}$ E. Zapata, and R. Ruiz, Respuestas institucionales ante la violencia escolar, 11(4) RA XIMHAI $475-491(2015)$.
} 
In the said laws, there are several conceptual problems, of roles and procedures. The constructs lack validity because they do not clearly state what the phenomenon of bullying really is, this is because they are based on paradigms that do not apply to the Mexican culture. School violence is reduced to two participants: The victim and the abuser. An important element, which has been described in several scientific reports is left out, this is the observer. Lastly, the laws do not describe the interaction between the people, the place and the elements outside the school environment, therefore the dynamics of the school violence are not completely covered.

The Supreme Court of Justice (SCJN) issued five theses related to bullying, in which they emphasize that: Because there is no clear academic and scientific consensus about the type of behavior in the phenomenon, the Supreme Court defines bullying as: "Any act or omission that continuously attacks a boy, a girl or adolescent, either physically, psychologically, emotionally, economically or sexually, while they are under the care of a school, either public or private". Therefore it is important to deal with the phenomenon of school violence and not only with bullying.

\section{Methodology for Diagnosing Alienation Parental}

Another phenomenon of antisocial behavior found in the family environment is Parental Alienation, which is also controversial due to the poor interaction between psychology and the law regarding the methodology of research and its unclear diagnosis. The reform of the Family Code of the State of Yucatan in 2015, was based on the principles of preserving the family as the fundamental institution for society; as the environment for the development of its members in the biological and social areas; protecting the integrity and dignity of the functional interactions, as stated in title first: Family Descriptions, Section 1: The object and General Regulations. In its different sections it strives for healthy relationships between the family members, but when the family cannot remain together, it promotes a separation that should be as less dysfunctional as possible, by using theoretical methods of diagnose and interventions such as therapeutic justice and cognitive-behavioral, among others. Such models are practiced mainly by psychologists that assist the judge in the decision making process.

Parental alienation, in a process of separation or divorce, is usually a human dysfunctional behavior that is exerted by the caregivers of the children and teenagers who are caught in between the conflict of their parents. This behavior is exerted by the parents, grandparents, uncles, new partners of the parents in conflict, as well as by the professionals that take 
part as assessors, companions or therapists. These last ones fall into professional malpractices either for not using appropriate scientific methodologies to solve the conflict or for being biased. All the above produce psychological dysfunctionalities in children and adolescents and other members of the family system. The malpractices of the psychologists also make an impact by generating false positives, as well as false negatives, when presenting the judge a biased and erroneous vision of the phenomenon.

The Parental Alienation Syndrome (PAS) was developed in the psychology field and it is defined as "the conscious act of one of the parents (or relative in custody) against another in order to lose affection, love, respect and regard from their children" ${ }^{27}$. Gardner $(2006)^{28}$, states that "it is manifested by a child's campaign of denigration against a parent, without any justification".

It is important to note that a group of psychologists defined PAS as a syndrome, not a disorder, because some professionals diagnose it as a disorder. A syndrome is a group of signs and symptoms that appear simultaneously and recurrently in the form of a clinical pattern. A disorder: is a clinically significant syndrome associated to a deterioration in one or more functional areas. The previous definitions challenge the diagnostic abilities of the professionals. And whether they considered the three basic criteria in any diagnosis. Such criteria are: Temporality: Period during which the symptoms and signs are observed; frequency: The minimal number of signs and symptoms necessary to consider it a disorder; and functionality or dysfunctionality of the disorder: The impact in the different areas of their lives (family, friend, school, etc.). And lastly, it must distinguish the clinical pattern from other disorders, this practice is called differential diagnosis. Psychologists often commit the errors described earlier in their diagnosis, because they take into account symptom patterns but they do not consider aspects such as temporality, the impact of the disorder and they are unable to perform a differential diagnosis.

In the Family Code of the State of Yucatan, Chapter 1, Section 280 Parental Alienation is defined: Whoever has the parental authority must promote respect and personal contact of the minors with the parent who also has parental authority, therefore any act of manipulation or parental alienation with the purpose of developing rejection, resentment, aversion, animosity or fear against the other parent is prohibited.

\footnotetext{
${ }^{27}$ A. T. Huerta, El síndrome de alienación parental: una forma de maltrato. Editorial EOS (2012).

${ }^{28}$ R. A. Gardner, The InTERnATIONAL HandboOK OF PARENTAL Alienation Syndrome:

Conceptual, Clinical and Legal Considerations (S. R. Sauber, and D. Lorandos eds., Vol. 1108, Charles C Thomas Publisher 2006).
} 
Parental Alienation Syndrome (PAS) is a construct that comes from the psychology field and it is not considered a disorder but a syndrome, because it does not define the minimum number of symptoms, neither the temporality of the demonstration of symptoms and signs, neither the degree of impact in different areas in the person's life. Parental Alienation is a legal definition. The risks of making these mutations from a professional area to another without rigorous scientific research leave the judiciary defenseless and conflicted, because they have to asses evidence based on arguments of doubtful scientific validity and reliability.

Richard Gardner $(2006)^{29}$ states that: a diagnostic of PAS has to be based first on the level of the symptoms on the alienating parents and then on those of the children, therefore any judicial decision has to follow this sequence. Before making a diagnosis of PAS it is important to make sure that the alienated parent is not being rejected by justified reasons, such as aggressive behavior against their children. The following procedure is recommended to be applied on people involved in the alienation, depending on their role in the parental alienation. First, make sure that the alienated parent had not provoked the rejection of the child. Second, identify the symptoms of alienating parents, and Third, Evaluate the children allegedly alienated. These steps will lead to confirmation or rejection of the hypothesis, as recommended by Richard Gardner $(2006)^{30}$.

1. It is necessary to investigate if the child or teenager has had experiences with the alienated father that justify their feelings of rejection. Should this be the case the diagnosis of parental alienation is not necessary. This procedure for the evaluation of the Parental Alienation Syndrome, aims to reduce the attribution error, or false positive, when PAS does not exist.

2. It evaluates if one or both parents are exerting alienation on the child or teenager, or the alienation is directed by other people such as relatives or professionals caregivers in charge or the children or adolescents. If it is confirmed that some of the family members mentioned above are participating in the alienation, their alienation personality profile need to be assessed, as well as their possible motives. It starts by evaluating the possible alienators, in order to avoid the attribution bias, based on the symptoms that could be found in the children and teenagers allegedly alienated.

3. Identification of signs and symptoms of PAS in the children and teenagers. Through the testimonies of the children or teenagers, and expanding the information with the parents, extended family and other social circles, like the children's school and friends. Behaviors that reflect symptoms and signs, that

\footnotetext{
${ }^{29}$ R. A. Gardner, The InTERnational Handbook of Parental Alienation Syndrome: Conceptual, Clinical and Legal Considerations (S. R. Sauber, and D. Lorandos eds., Vol. 1108, Charles C Thomas Publisher 2006).

${ }^{30}$ Ibid.
} 
lead to confirm or refuse the hypothesis that one or both parents exert aggression against the child or teenage must be identified, these include: aggressive, irate or violent behavior, and if they are redirected to one or other loved ones. The above should lead to take two factors into account. First, if the aggressive behaviors, irate and violent, are being exerted directly or indirectly, and second, if these symptoms and signs are related to some another disorders, like post-traumatic stress, or anxiety. ${ }^{31}$

The professionals in charge of making the assessment should define the methodology to be used to justify the psychological criteria of Parental Alienation Syndrome applied in the diagnosis, as describe in the Family Code of the State of Yucatan $(2015)^{32}$. One strategy is to define the concepts and constructs to be considered valid and reliable.

Research results lead to establish the criteria to identify an alienated child. Depending on the severity of the PAS, a child can exhibit all or some of the following behaviors ${ }^{33}$ :

1. The children join the alienator and participate actively in a campaign of denigration against the other parent, the children show their feelings in words and actions. The characteristic symptom is that the children hate the parent without remorse or guilt.

2. The reasons alleged to justify the deprecation towards the parent are often feeble, frivolous or absurd.

3. The hostility against the rejected parent lacks the normal ambivalence in the human relations.

4. The children assert that the decision to hate the targeted parent is theirs alone, that nobody has influenced them and that they adopted such attitude themselves.

5. The children support reflexively the favored parent.

6. The children show disdain without remorse for their feelings against the targeted parent.

7. Borrowed scenarios are evident: The children talk about events that are not real, or that they may have heard

8. The animosity expands to the parent's extended family and to those associated with the hated parent.

Alienated children show the following characteristics:

- They feel a relentless hate towards the alienated parent.

- They repeat like parrots what the obsessive, alienator parent says.

\footnotetext{
${ }^{31}$ P. Dzib-Aguilar, Clase de posgrado de teoríascriminológicas (Presentación, Claustro de Chihuahua, México 2016).

${ }^{32}$ Código de Familia para el Estado de Yucatán, En el DiarioOficial del Gobierno del Estado de Yucatán, Mérida, Yucatán, Última Reforma D. O.12-Junio-2015 (2015).

${ }^{33}$ D. C. Ran, El Espectro del Síndrome de Alienación Parental. Parte I-A., 15(3) PERIÓDICO AMERICAN DE PSICOLOGÍA Forense (1997a).
} 
- The children do not want to visit or spend time with the targeted parent.

- Many of the children's opinions coincide with those of the alienator.

- Such opinions are usually false or irrational illusions.

- Do not feel intimidated by going to court.

- The reason they provide about their personal experiences with the hated parent are usually influenced by the obsessive alienator.

- There is no ambivalence in their feelings, hatred prevents them from seeing what is good in the parent.

- They do not feel guilty about their behavior towards the hated parent.

- They take sides with the alienator and they work together to denigrate the hated parent.

- The obsessive hatred felt by the children expands to the parent's extended family, without remorse or guilt.

- They can appear to be healthy and normal until they are asked about the alienated parent, and that is what triggers their hatred.

The evaluation of the evidence is responsibility of the judge, the forensic psychological assessment is a scientific and methodological responsibility of the legal psychologist. The scientific methodology must respond to the objective of the judicial evaluation to comply with the appropriate professional practice and to contribute with data for the evidence that provide elements for the judge.

\section{THERAPEUTIC JUSTICE IN YUCATAN}

More interdisciplinary research works is needed in order to achieve the objective of administering justice based on a legally bound scientific framework. Therefore a descriptive type research among civil servants of the Higher Court of Justice of the State of Yucatán was carried out. The objective was to know, in 2014, what was the social perception about Therapeutic Justice in Yucatán, Mexico. The following results were obtained.

The legislative system and the administration of justice have been reformed in México since a decade ago, bringing changes in the legal system, as well as the social perception. There is no relation between the legislative adjustments and mental health practice. They are perceived as two different, and often opposite, processes. However, the legislative changes in Mexico related to the administration of justice are framed in a country shaken by organized crime and corruption, besides multicultural and ethnic issues; this scenario has affected the application of law and its 
consequences on the individuals. For this reason, it is urgent to create social, political and juridical awareness about Therapeutic Justice, that has become relevant in other countries in the last 20 years. Therapeutic Justice conceptualizes the law as a social strength that produces behaviors and consequences, humanizes the law and it is concerned about the psychological and emotional sides of the law and the legal processes. It focuses on identifying and improving those aspects of the law that encourage change and rehabilitation of the offenders.

The objective of the research was: To determine if therapeutic justice is kwon by the members of different professions.

Methodology: A survey was applied to a sample of 60 people of different professions who were selected randomly at the High Court of Justice, in Mérida, Yucatán, Mexico. A non parametric correlation was applied that was adjusted to the different variables.

Results: With a 95\% confidence it can be asserted that there is not a significant relation between age and the knowledge on therapeutic justice. The professions with more knowledge about therapeutic justice are Social work $(100 \%)$ and Psychology $(60 \%)$; whereas the Legal profession $(20 \%)$ is the one with less knowledge about it. The survey provided data about the perception of therapeutic justice as a means to improve the interdisciplinary work. In this regard, Social work (100\%) and Psychology $(80 \%)$ are the professions that consider that the said branch of the law is totally useful. On the other hand, the majority of the legal professionals think that the therapeutic justice is totally useful although $80 \%$ of them lack knowledge about this branch.

We can conclude that: based on the previous discussion, the administration of justice in Mexico is following the right path to incorporate valid and reliable scientific methodologies, to develop the competencies in its participants and to implement interdisciplinary work. It is important to note that it requires more institutional work to achieve functional dynamics between law and science.

\section{CONCLUSION}

In an effort to move towards a better and fairer system of justice, the country has perhaps carried out one of the most important and transcendent reforms of the last decades, implementing the Orality System, and with it the incorporation of the scientific method of a much more important way, thus making science available to the system in the search for truth and justice. The relationship between science and justice, although necessary is 
also complicated, since it involves adopting scientific thinking in the legal process, as well as the latest advances in science in understanding and explaining violence, crime and antisocial behavior, which Requires among other things a deep training and awareness of the actors and officials that make up the system.

Social phenomena such as violence and delinquency, given their complexity, are the result of the interaction of multiple variables that mix and conjugate with each other. Only by studying and analyzing these variables and their structure can we move towards a demarcation and clearer understanding of the social problems that impact our society today and which have repercussions both for the individual and for his family and school group; And which in turn has an impact on the economic, legal and even political system. In the specific case of school violence, it is necessary to migrate from an approach based on psychopathological explanations of the problem to theoretical approaches that integrate family, social, cultural and relational elements. This not only has repercussions at the level of procurement and justice, but also at the legislative level, since it is not possible to legislate what is not known with certainty.

On the other hand we have in the area of Family Law parental alienation, a term that has become "fashionable" in recent years. This term has generated controversy due to the poverty in the interaction between the psychology and the law in relation to its methodology of study and its diagnostic indetermination. The recommendation here is that the professionals who perform the assessment clearly establish the methodology used to justify the psychological criteria of the Parental Alienation Syndrome applied in the diagnosis of Parental Alienation as described in the Family Code for the State of Yucatan (2015) ${ }^{34}$ But above all it receives specialized training. But more important is the revision of the definition of this term, both in the legislation and in the definitions from legal and forensic psychology, in order to reach a consensus between psychology and law. Interdisciplinary work is urgent if we want to achieve justice in a scientific framework that adheres to legality.

\footnotetext{
${ }^{34}$ Código de Familia para el Estado de Yucatán, En el DiarioOficial del Gobierno del Estado de Yucatán, Mérida, Yucatán, Última Reforma D. O.12-Junio-2015 (2015).
} 